\title{
Kinetics and Mechanism of Oxidation of L-Ascorbic Acid by $\operatorname{Pt}(\mathrm{IV})(\mathbf{a q})$ in Aqueous Hydrochloric Acid Medium
}

\author{
Sadhana Senapati, ${ }^{1}$ S. P. Das, ${ }^{2}$ and A. K. Patnaik ${ }^{2}$ \\ ${ }^{1} P G$ Department of Chemistry, Utkal University, Odisha, Bhubaneswar 754004, India \\ ${ }^{2}$ PG Department of Chemistry, Ravenshaw University, Odisha, Cuttack 753003, India
}

Correspondence should be addressed to S. P. Das, dassmrutiprava@yahoo.in

Received 30 June 2012; Accepted 20 September 2012

Academic Editor: Marc Koper

Copyright ( 2012 Sadhana Senapati et al. This is an open access article distributed under the Creative Commons Attribution License, which permits unrestricted use, distribution, and reproduction in any medium, provided the original work is properly cited.

\begin{abstract}
Reduction of $\left[\mathrm{PtCl}_{6}\right]^{2-}$ by L-ascorbic acid $\left(\mathrm{H}_{2} \mathrm{ASc}\right)$ in $0.1 \mathrm{M}$ aqueous acid medium has been investigated spectrophotometrically under pseudo-first order condition at $\left[\mathrm{PtCl}_{6}\right]^{2-}=0.005-0.007 \mathrm{~mol} \mathrm{dm}^{-3}, 0.05 \leq\left[\mathrm{H}_{2} \mathrm{ASc}\right] / \mathrm{mol} \mathrm{dm}^{-3} \leq 0.3,298 \mathrm{~K} \leq T \leq 308 \mathrm{~K}$, $\left[\mathrm{H}^{+}\right]=0.14 \mathrm{~mol} \mathrm{dm}^{-3}, I=0.5 \mathrm{~mol} \mathrm{dm}^{-3}$. The redox reaction follows the rate law: $d[\mathrm{Pt}(\mathrm{IV})] / d t=k\left[\mathrm{H}_{2} \mathrm{ASc}\right][\mathrm{Pt}(\mathrm{IV})]$, where $k$ is the second-order rate constant and $\left[\mathrm{H}_{2} \mathrm{ASc}\right]$ is the total concentration of ascorbic acid. Electron transfer from [ $\left.\mathrm{H}_{2} \mathrm{ASc}\right]$ to $\mathrm{Pt}(\mathrm{IV})$ center leading to the release of two halide ions and formation of the reaction products, square planner Pt(II) halide complex, and dehydrated ascorbic acid is suggested. This redox reaction follows an outersphere mechanism as Pt(IV) complex is substituted inert. Activation parameters were calculated corresponding to rate of electron transfer reaction $k$. Activation parameters favor the electron transfer reaction.
\end{abstract}

\section{Introduction}

The redox reaction of $\mathrm{L}$-ascorbic acid is of fundamental interest in chemistry, biochemistry, pharmacology, and several areas of medicine. It is used as a reducing agent with one or two electron reductants in chemical and biological systems [1-7]. Rate of reduction by ascorbic acid depends on nature of oxidant and $\mathrm{pH}$ of the medium. Different mechanisms have been proposed for the reaction between ascorbic acid and metal complexes [5-13].

In recent years there has been significant interest in the chemistry of square planar platinum (II) complex for remarkable anticancer properties [14-16]. Several thousand potentially biological active $\mathrm{Pt}(\mathrm{IV})$ complexes have been reported for anticancer properties [16].

We report here the interaction of ascorbic acid with $\mathrm{Pt}(\mathrm{IV})(\mathrm{aq})$. Ascorbic acid is a good biological reducing agent. $\mathrm{Pt}(\mathrm{IV})(\mathrm{aq})$ appeared attractive because these octahedral complexes are usually substitution inert and require reduction to $\mathrm{Pt}(\mathrm{II})$ species to act as potential anticancer drugs. The anticancer activity of $\mathrm{Pt}(\mathrm{IV})$ complexes is likely to be due to effective platinum (IV) transport into the cell followed by reduction to the more reactive platinum (II) compounds. The knowledge of the reactivity of $\mathrm{Pt}(\mathrm{IV})$ compounds towards the reduction by potential bioreductant like ascorbic acid may be important for understanding the mechanism of where antitumor activity as well as for designing new compounds with the least side effect. Chois et al. [17] reported that there is a correlation between the rate of the reduction and anticancer activity in a series of homologous $\mathrm{Pt}(\mathrm{IV})$ complex without going into the details of reaction mechanism. The present study was undertaken with the aim of extending the knowledge of the kinetics and thermodynamic parameters that characterized the reduction of $\mathrm{Pt}(\mathrm{IV})$ complex by ascorbic acid and clarifying the mechanism details using the model complex $\mathrm{PtCl}_{6}{ }^{2-}$.

\section{Experimental}

2.1. Materials. All chemicals used were analaR grade. Lascorbic acid (Merck) and sodium hexachloro-platinate (Merck) were used as received. Sodium hexachloroplatinate stock solution was prepared with 0.1 M HCL. Solutions of different concentrations were prepared by proper dilution of 


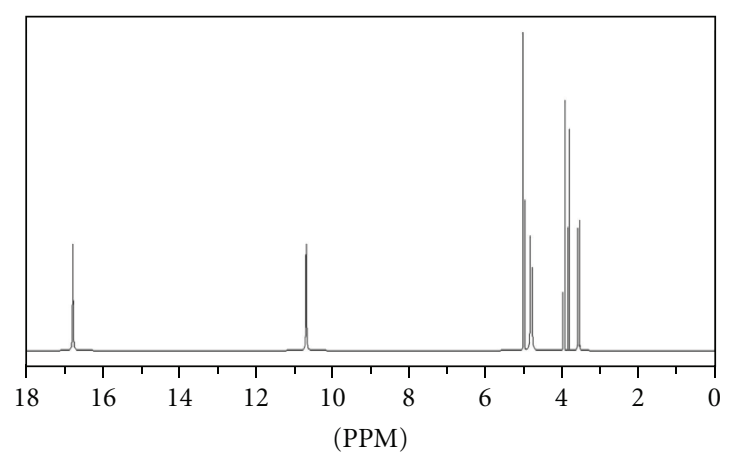

(a)

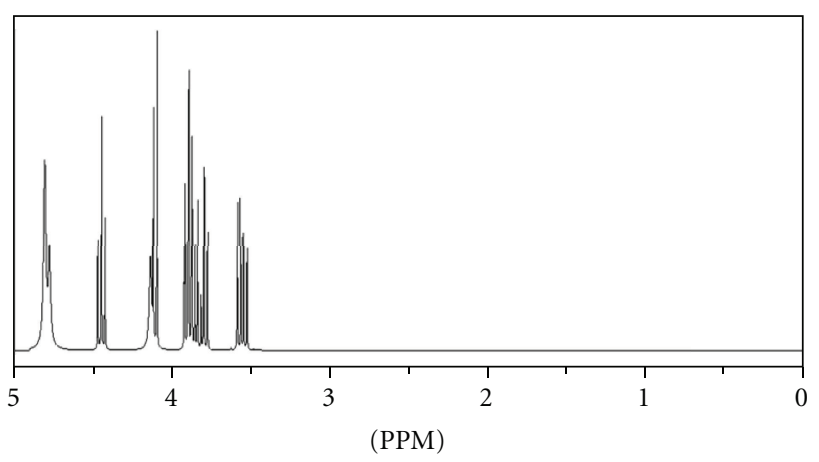

(b)

Figure 1: (a) ${ }^{1} \mathrm{H}$ NMR spectra of L-ascorbic acid. (b) ${ }^{1} \mathrm{H}$ NMR spectra of dehydroascorbic acid.

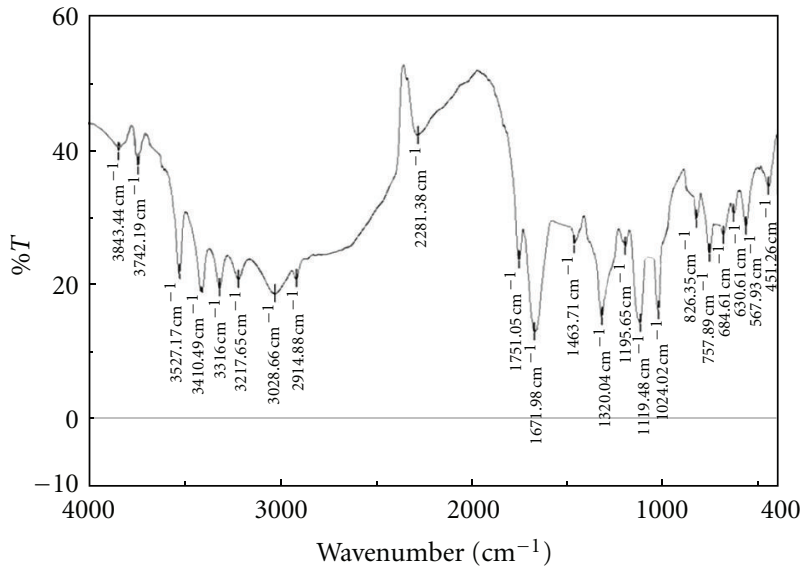

(a)

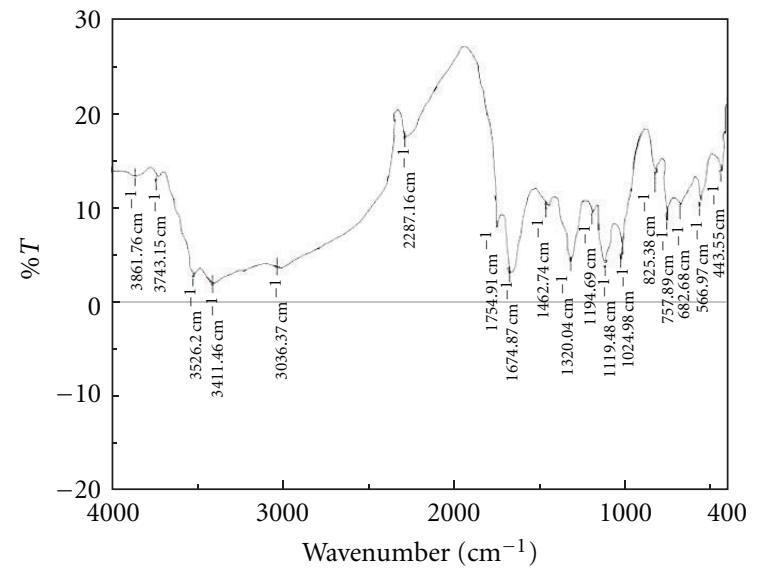

(b)

FIGURE 2: (a) IR spectra of ascorbic acid. (b) IR spectra of dehydroascorbic acid.

stock solution. Fresh solutions were used for kinetics measurements. Ionic strength was maintained with $\mathrm{NaClO}_{4}$. All solutions were prepared in freshly prepared double distilled water using an all-glass distillation apparatus containing $\mathrm{KMnO}_{4}$.

2.2. Kinetics. The kinetics of oxidation of L-ascorbic acid by sodium hexachloroplatinate in aqueous acid medium was studied spectrophotometrically under pseudo-first order conditions by keeping the concentration of ascorbic acid at least ten times in excess over Pt(IV) complex. The decrease of absorbance with time was monitored at $457 \mathrm{~nm}$ using conventional mixing technique in Systronic 2202 UV-VIS spectrophotometer equipped with a thermostatic bath for temperature control. The rate constant $\left(k_{\mathrm{obs}}\right)$ was calculated from the slope of $\ln \left(A_{t}-A_{\infty}\right)$ versus $t(\mathrm{~s})$ plot from the relationship

$$
\ln \left(A_{t}-A_{\infty}\right)=\ln \left(A_{0}-A_{\infty}\right)-k_{\mathrm{obs}} \cdot t,
$$

where $A_{0}, A_{t}, A_{\infty}$ denote optical density of the reaction mixture at zero time, time $t$, and at infinity, respectively. $A_{\infty}$ was measured after completion of the reaction mixture (after $24 \mathrm{hrs}$ of mixing), were absorbance becomes almost constant.
The correlation coefficients $\left(R^{2}\right)$ of the plots used to determine $k_{\text {obs }}$ were found to be 0.99 in most of the cases. All calculations were made on a PC using least square program.

\subsection{Stoichiometry and Identification of Reaction Products.} The stoichiometry for the reduction of $\left[\mathrm{PtCl}_{6}\right]^{2-}$ by ascorbic acid was determined by iodine titration method. Excess of ascorbic acid is allowed to react with fixed amount of $\left[\mathrm{PtCl}_{6}\right]^{2-}$. Titrating the ascorbic acid with iodine before and after the reaction indicates a $1: 1$ stoichiometry between $\mathrm{Pt}(\mathrm{IV})$ and L-ascorbic acid

$$
\begin{array}{r}
\mathrm{H}_{2} \mathrm{ASc}+\mathrm{PtCl}_{6}{ }^{-2} \longrightarrow \mathrm{DHA}+\left[\mathrm{PtCl}_{4}\right]^{2-}+2 \mathrm{H}^{+}+2 \mathrm{Cl}^{-} \\
(\mathrm{DHA}=\text { dehydroascorbate }) .
\end{array}
$$

The product of redox reaction was identified as dehydroascorbate along with $\mathrm{Pt}(\mathrm{II})$. The product DHA was confirmed by ${ }^{1} \mathrm{H}$ NMR (see Figures $1(\mathrm{a})$ and $1(\mathrm{~b})$ ) and FTIR (see Figures 2(a) and 2(b)). Pt(II) was identified by UVVIS spectra after $24 \mathrm{~h}$ (Figure 3(b)). Figure 1(a) shows peaks at $\delta 4.78,4.81,10.68(\mathrm{enol}), 16.77(\mathrm{enol})$ corresponding to four $\mathrm{OH}$ groups, $\delta 5.0$ for $\mathrm{CH}$ of furanone, $\delta 3.93$ corresponding to methine $(\mathrm{CH})$ group in ascorbic acid, whereas 


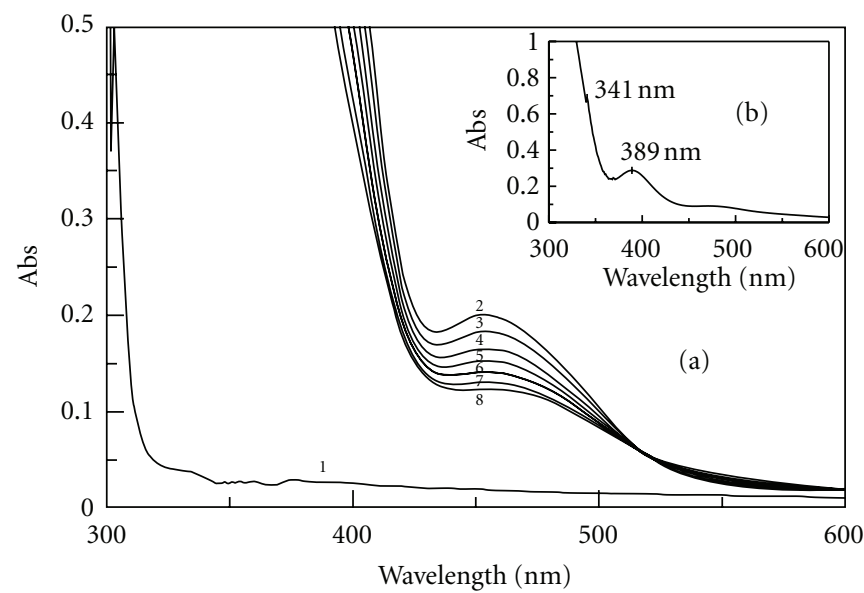

FIGURE 3: (a) UV-VIS spectral scan of reaction mixture of L-ascorbic acid and sodium hexachloroplatinate, $\left[\mathrm{H}^{+}\right]=0.14 \mathrm{~mol} \mathrm{dm}^{-3}, I=$ $0.5 \mathrm{~mol} \mathrm{dm}^{-3}$ at $303 \mathrm{~K}$. (1) (L-ascorbic acid) $=1.0 \times 10^{-1} \mathrm{~mol} \mathrm{dm}^{-3}$, (2) (sodium hexachloroplatinate) $=5.0 \times 10^{-3} \mathrm{~mol} \mathrm{dm}^{-3},(3) \mathrm{immediately}$ after mixing, (4) after 15 minutes, curve (5-8) $\Delta t=5$ minutes. (b) Inset: spectra of the above reaction mixture after $24 \mathrm{hr}$.

TABle 1: Pseudo-first order rate constant $\left(k_{\mathrm{obs}}\right)$ data at different temperatures.

\begin{tabular}{cccccc}
\hline$\left[\mathrm{H}^{+}\right]\left(\mathrm{mol} \mathrm{dm}^{-3}\right)$ & & \multicolumn{3}{c}{$10^{3} k_{\text {obs }}$ (pseudo-first order rate constant) $\left(\mathrm{s}^{-1}\right)$} \\
& {$\left[\mathrm{H}_{2} \mathrm{ASc}\right]\left(\mathrm{mol} \mathrm{dm}^{-3}\right)$} & $293 \mathrm{~K}$ & $298 \mathrm{~K}$ & $303 \mathrm{~K}$ & $308 \mathrm{~K}$ \\
\hline \multirow{3}{*}{0.14} & 0.05 & 1.215 & 2.000 & 4.000 & 7.700 \\
& 0.10 & 1.831 & 3.000 & 7.000 & 13.400 \\
& 0.15 & 2.303 & 4.000 & 9.800 & 17.500 \\
& 0.20 & 2.817 & 5.000 & 12.500 & 24.000 \\
& 0.25 & 3.111 & 6.000 & 15.500 & 29.000 \\
\hline
\end{tabular}

Figure 1 (b) shows peaks at $\delta 4.81$ and 4.78 , peak at $\delta 4.45$, 4.11 corresponding to $\mathrm{CH}$ group in butyrolactone, and peak at $\delta 3.90$ corresponding to methine $(\mathrm{CH})$. All peaks of ${ }^{1} \mathrm{H}$ NMR Spectra of Figure 1(b) corresponds to dehydroascorbic acid. IR spectra of Figure 2(b) show the presence of two $\mathrm{OH}$ groups due to the broad peaks at $3411.5 \mathrm{~cm}^{-1}$ and $3526 \mathrm{~cm}^{-1}$, whereas there are four $\mathrm{OH}$ groups in Figure 2(a) corresponding to peaks $3216 \mathrm{~cm}^{-1}, 3316 \mathrm{~cm}^{-1}, 3411.5 \mathrm{~cm}^{-1}$, and $3527 \mathrm{~cm}^{-1}$. In Figure 2(b), two peaks at $1675 \mathrm{~cm}^{-1}$ corresponds to $\mathrm{C}-\mathrm{O}, 1755 \mathrm{~cm}^{-1}$ corresponds to $\mathrm{C}=\mathrm{O}$ groups. All the IR spectra of Figure 2(b) corresponds to dehydroascorbic acid.

\section{Results and Discussion}

L-ascorbic acid $\left(\mathrm{H}_{2} \mathrm{ASc}\right)$ has two acidic protons $\left(\mathrm{pK}_{1}=\right.$ 4.04 and $\left.\mathrm{pK}_{2}=11.34\right)$ [18] and is a strong reducing agent $\left(E^{0}=0.390 \mathrm{~V} \mathrm{NHE}\right)$ in aqueous solutions. The electron transfer reaction between $\mathrm{PtCl}_{6}{ }^{2-}$ and $\mathrm{L}$-ascorbic acid was investigated by changing (L-ascorbic acid) in the range 0.05 to $0.3 \mathrm{~mol} \mathrm{dm}^{-3}$ at $\left[\mathrm{H}^{+}\right]=0.14 \mathrm{~mol} \mathrm{dm}^{-3}$ and $I=0.5 \mathrm{~mol} \mathrm{dm}^{-3}$. Temperature variation was carried out in the range $293 \mathrm{~K}$ to $308 \mathrm{~K}$. The UV-VIS spectral scan (see Figure $3(\mathrm{a})$ ) of the reaction mixture was over the wavelength range $350 \leq \lambda(\mathrm{nm}) \leq 600$. Gradual decrease of absorbance with time was observed without the formation of isosbestic point and without shifting of $\lambda_{\max }$ (maximum wavelength) indicating the fact that there is no formation of intermediate species. After a long interval of time (after $24 \mathrm{~h}$ ), the peak at $457 \mathrm{~nm}$ disappeared completely and two new peaks (see Figure 3(b)) at $341 \mathrm{~nm}$ and $389 \mathrm{~nm}$ appeared corresponding to square plannar $\mathrm{Pt}(\mathrm{II})$ complex. In this redox process, octahedral $\mathrm{Pt}(\mathrm{IV})$ is reduced to square plannar $\mathrm{Pt}(\mathrm{II})$. Therefore this reaction is better classified as reductive elimination reaction [19]. IR and ${ }^{1} \mathrm{H}$ NMR spectra showed the formation of dehydroascorbate along with $\mathrm{Pt}(\mathrm{II})$. Similar product was reported by others [20-22] for the reaction between $\mathrm{Pt}(\mathrm{IV})$ and different reductants. Plots of pseudofirst order rate constant $\left(k_{\text {obs }}\right)$ versus $\left[\mathrm{H}_{2} \mathrm{ASc}\right]_{\text {total }}$ were linear with zero intercept (see Figure 4). The fact indicates no reverse electron transfer reaction. The redox reaction follows the second order rate law given by (3)

$$
\begin{gathered}
\frac{-d[\mathrm{Pt}(\mathrm{IV})]}{d t}=k_{\mathrm{obs}}[\mathrm{Pt}(\mathrm{IV})]=k\left[\mathrm{H}_{2} \mathrm{ASc}\right][\mathrm{Pt}(\mathrm{IV})]_{\text {total }} \\
k_{\mathrm{obs}}=k\left[\mathrm{H}_{2} \mathrm{ASc}\right]_{\text {total }},
\end{gathered}
$$

where $k$ denotes second order rate constant. We arrive at the reaction shown in (4)

$$
\begin{aligned}
& \mathrm{H}_{2} \mathrm{ASc} \rightleftharpoons \mathrm{HASc}^{-}+\mathrm{H}^{+} \quad\left(\mathrm{pk}_{1}=4.04\right) \\
& \mathrm{Pt}(\mathrm{IV})+\mathrm{HASc}^{-} \stackrel{k}{\longrightarrow} \mathrm{Pt}(\mathrm{II})+\mathrm{DHA}
\end{aligned}
$$




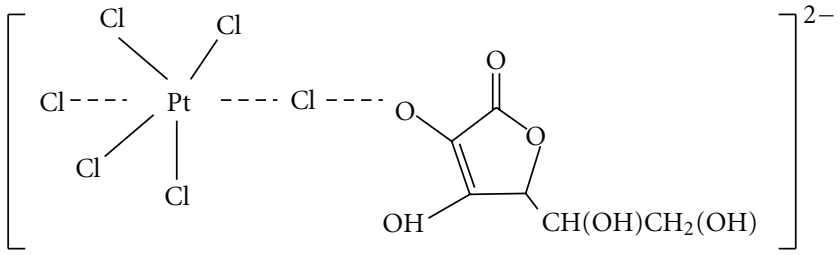

Scheme 1

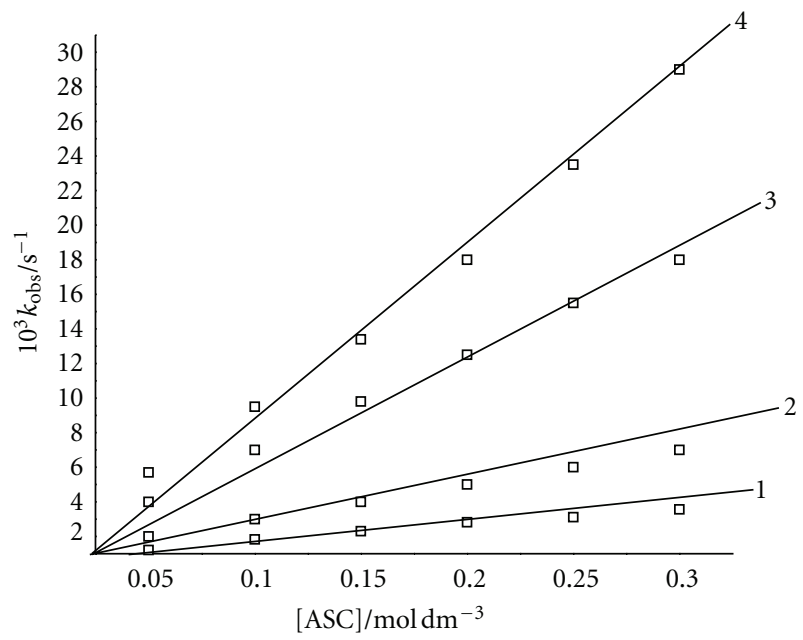

Figure 4: The plot of $k_{\mathrm{obs}}$ versus $\left[\mathrm{H}_{2} \mathrm{Asc}\right]$ at temperature (1) $293 \mathrm{~K}$, (2) $298 \mathrm{~K}$, (3) $303 \mathrm{~K}$, (4) $308 \mathrm{~K}$.

TABLE 2: Calculation of second order rate constant $k$ and activation parameters.

\begin{tabular}{lc}
\hline Temperature $(\mathrm{K})$ & $\begin{array}{c}10^{2} k(\text { rate of electron transfer reaction) } \\
\left(\mathrm{mol}^{-1} \mathrm{dm}^{3} \mathrm{~s}^{-1}\right)\end{array}$ \\
\hline 293 & 0.9 \\
298 & 2.0 \\
303 & 5.6 \\
308 & 9.4 \\
$\Delta \mathrm{H}^{\ddagger}$ (kilo joule per mole) & $11.88 \pm 1.31$ \\
$\Delta \mathrm{S}^{\ddagger}$ (Joule per Kelvin per & $-51.66 \pm 4.39$ \\
mole) & \\
\hline
\end{tabular}

The second-order rate constant $(k)$ for reduction of $\mathrm{Pt}(\mathrm{IV})$ was calculated using (4) by plotting $k_{\text {obs }}$ versus $\left[\mathrm{H}_{2} \mathrm{ASc}\right]$ as collected in Table 1 at four different temperatures from $293 \mathrm{~K}$ to $308 \mathrm{~K} . k$ data were used to calculate activation parameters as $\Delta \mathrm{H}^{\ddagger}=11.88 \pm 1.31 \mathrm{~kJ} \mathrm{~mol}^{-1}$ and $\Delta \mathrm{S}^{\ddagger}=-51.66 \pm$ $4.39 \mathrm{Jk} \mathrm{mol}^{-1}$ (see Table 2).

They are close to the reported value for similar systems $[18,19,23]$. The value of activation parameters is favorable for electron transfer reaction.

It is concluded that the redox reaction follows an outer sphere mechanism with the fact that Pt(IV) octahedral complex is substitution inert. The mechanism for reduction of $\mathrm{Pt}(\mathrm{IV})$ halide complex by biological reductant involve an attack by the reductant as a halide coordinated trans to good leaving groups forming a halide bridge activated in $\mathrm{Pt}(\mathrm{IV})$ complex which facilitates such rapid reductive elimination reaction $[20,23]$ (see Scheme 1).

A concerted two-electron transfer from ascorbate to $\mathrm{Pt}(\mathrm{IV})$ center leading to the release of two halide ions and formation of reaction products, $\mathrm{Pt}(\mathrm{II})$, dehydroascorbic acid are observed.

\section{Acknowledgment}

The authors are thankful to HOD Chemistry, Utkal University, for providing research facilities and also thankful to Prof. P. Mohanty (Rtd) for his help.

\section{References}

[1] E. Pelizzetti, E. Mentasti, E. Pramauro, and I. Ihaliz, Chemistry, vol. 15, p. 2829, 1976.

[2] E. Pelizzetti, E. Mentasti, and E. Pramauro, "Outer-sphere oxidation of ascorbic acid," Inorganic Chemistry, vol. 17, no. 5, pp. 1181-1186, 1978.

[3] D. H. Macartiney and A. Mc Auley, Canadian Journal of Chemistry, vol. 59, p. 132, 1981.

[4] Z. Amjad, J. C. Brodovitch, and A. McAuley, "Metal-ion oxidations in solution. Part XXI. Kinetics and mechanism of the reaction of ascorbic acid, hydroquinone, and catechol with 12tungstocobaltoate (III)," Canadian Journal of Chemistry, vol. 55, no. 20, pp. 3581-3586, 1977.

[5] K. Tsuleahara and Y. Yamamota, Bulletin of the Chemical Society of Japan, vol. 54, p. 2642, 1981.

[6] N. H. Williams and J. K. Yamdell, "Outer-sphere electrontransfer reactions of ascorbate anions," Australian Journal of Chemistry, vol. 35, no. 6, pp. 1133-1144, 1982.

[7] M. Kimura and S. Yamab, Journal of the Chemical Society, Dalton Transactions, p. 423, 1982.

[8] P. Martinez, J. Zuluaga, J. Kralt, and R. Van Eldik, "Kinetics and mechanism of the oxidation of L-ascorbic acid by trisoxalatocobaltate(III) in basic aqueous solution," Inorganica Chimica Acta, vol. 146, no. 1, pp. 9-12, 1988.

[9] D. Pinnell and R. B. Jordan, "Kinetics of reduction of cobalt(III)-ammine complexes by dithionite," Inorganic Chemistry, vol. 18, no. 11, pp. 3191-3194, 1979.

[10] S. Abey Okada, H. Horic, and S. Taniguchr, Journal of the Chemical Society, Perkin Transactions, vol. 7, p. 5, 1987.

[11] D. H. Macartney and N. Sutin, Inorganica Chimica Acta, vol. 74, p. 221, 1983.

[12] E. Pelizzetti and E. Mentasti, Journal of the Chemical Society, Dalton Transactions, p. 61, 1978.

[13] M. M. Taqui khan and R. S. Sukla, Inorganica Chimica Acta, p. $149,1989$.

[14] N. Farrel, R. Ugo, and B. R. James, Eds., Catalysis By Metal Complexes, vol. 11, Kluwer, Dordrecht, The Netherlands, 1989.

[15] R. B. Weiss and M. C. Christian, "New cisplatin analogues in development: a review," Drugs, vol. 46, no. 3, pp. 360-377, 1993.

[16] M. C. Keage, M. J. Kelland, L. R. Neidles, and M. J. Warning, Eds., Molecular Aspects of Anticover Drug DNA Interactions, vol. 1, CRC Press, New York, NY, USA, 1993.

[17] Chois, C. Filotto, M. Bisanzo et al., "Reduction and anticancer activity of platinum(IV) complexes," Inorganic Chemistry, vol. 37, pp. 2500-2504, 1988.

[18] K. Moribe, W. Limwikrant, K. Higashi, and K. Yamamoto, "Drug Nanoparticle Formulation Using Ascorbic Acid Derivatives," Journal of Drug Delivery, vol. 2011, Article ID 138929, pp. 1-9, 2011. 
[19] K. Lemma, A. Sargeson, and L. I. Elding, "Kinetics and mechanism for reduction of oral anticancer platinum(IV) dicarboxylate compounds by L-ascorbate ions," Journal of the Chemical Society, Dalton Transactions, no. 7, pp. 1167-1172, 2000.

[20] T. Shi, J. Berglund, and L. I. Elding, "Kinetics and mechanism for reduction of trans-dichlorotetracyanoplatinate(IV) by thioglycolic acid, l-cysteine, dl-penicillamine, and glutathione in aqueous solution," Inorganic Chemistry, vol. 35, no. 12, pp. 3498-3503, 1996.

[21] T. Shi, J. Berglund, and L. I. Elding, "Reduction of transdichloro- and trans-dibromo-tetracyano-platinate(IV) by Lmethionine," Journal of the Chemical Society, Dalton Transactions, no. 12, pp. 2073-2077, 1997.

[22] K. Lemma, T. Shi, and L. I. Elding, "Kinetics and mechanism for reduction of the anticancer prodrug trans, trans, trans$\left[\mathrm{PtCl}_{2}(\mathrm{OH})_{2}\left(\mathrm{c}-\mathrm{C}_{6} \mathrm{H}_{11} \mathrm{NH}_{2}\right)\left(\mathrm{NH}_{3}\right)\right]$ (JM335) by thiols," Inorganic Chemistry, vol. 39, no. 8, pp. 1728-1734, 2000.

[23] L. Kelemu, D. A. House, N. Retta, and L. I. Eldirs, "Kinetics and mechanism for reduction of halo- and haloam $(\mathrm{m})$ ine platinum(IV) complexes by L-ascorbate," Inorganica Chimica Acta, vol. 331, pp. 98-108, 2002. 


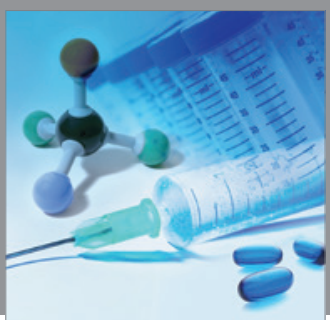

International Journal of

Medicinal Chemistry

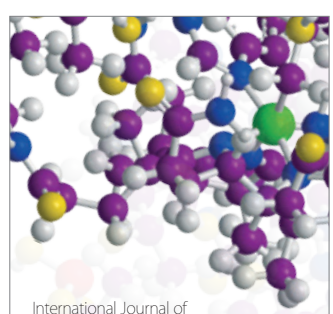

Carbohydrate Chemistry

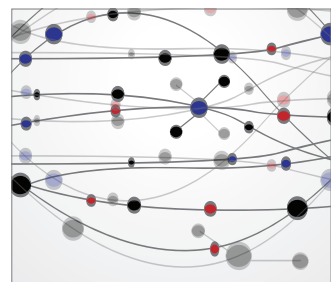

The Scientific World Journal
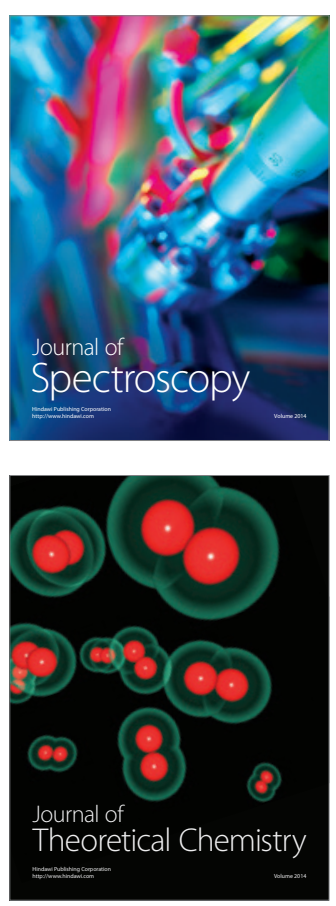
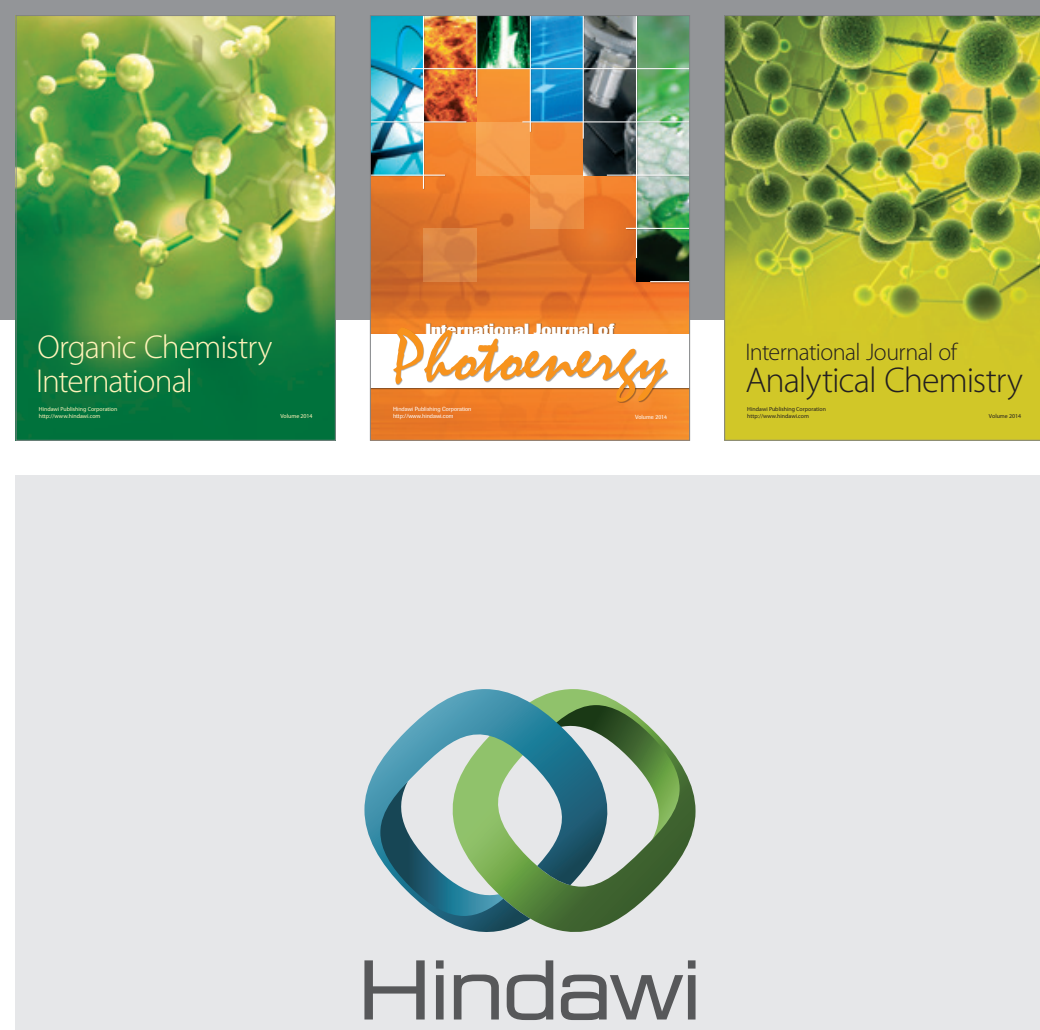

Submit your manuscripts at

http://www.hindawi.com
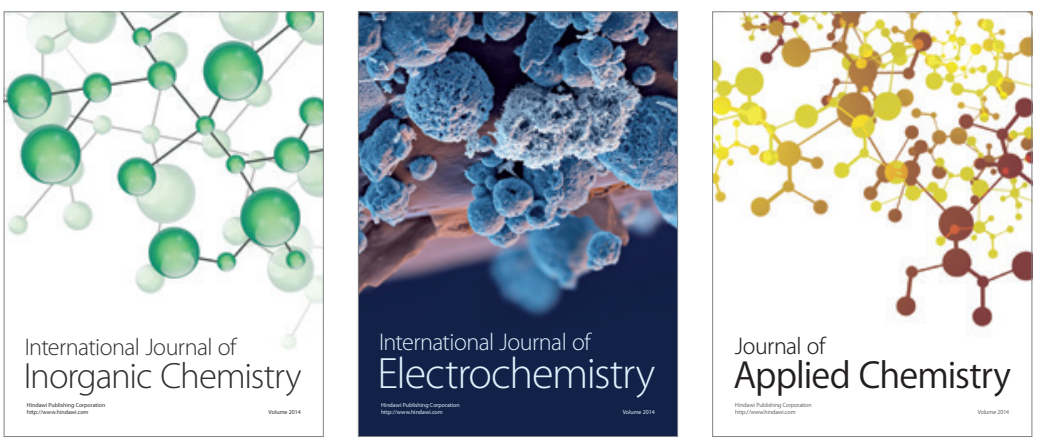

Journal of

Applied Chemistry
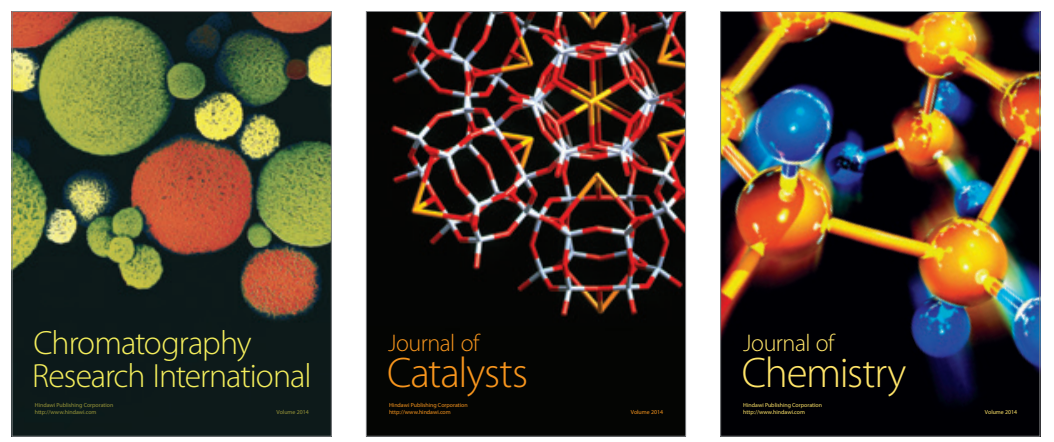
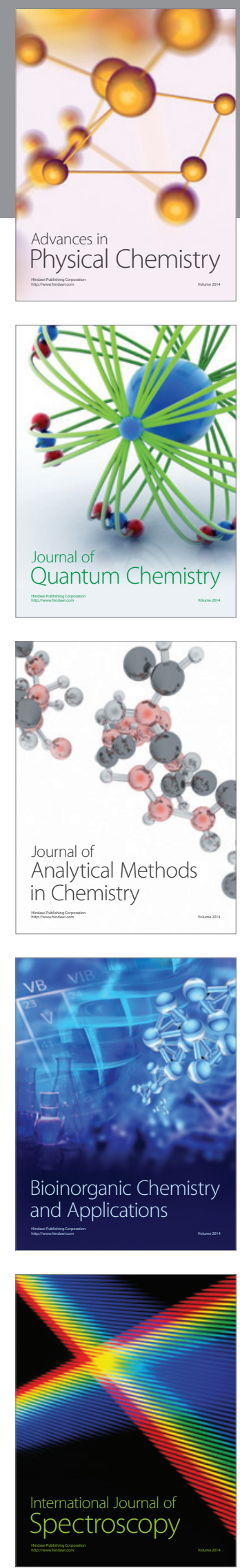